\title{
Energy Supply Characteristics of a Combined Solar Cell and Diesel Engine System with a Prediction Algorithm for Solar Power Generation
}

\author{
Abeer Galal El-SAYED ${ }^{* *}$ and Shin'ya OBARA ${ }^{* *}$ \\ ${ }^{* *}$ Department of Electrical and Electronic Engineering, Kitami Institute of Technology \\ 165 Koen-cho, Kitami, Hokkaido 090-8507, Japan \\ E-mail: obara@mail.kitami-it.ac.jp
}

\begin{abstract}
The production of electricity from the solar cells continues to attract interest as a power source for distributed energy generation. It is important to be able to estimate solar cell power to optimize system energy management. This paper proposes a prediction algorithm based on a neural network $(\mathrm{NN})$ to predict the electricity production from a solar cell. The operation plan for a combined solar cell and diesel engine generator system is examined using the NN prediction algorithm. Two systems are examined in this paper: one with and one without a power storage facility. Comparisons are presented of the results from the two systems with respect to the actual calculations of output power and the predicted electricity production from the solar cell. The exhaust heat from the engine is used to supply the heat demand. A back-up boiler is operated when the engine exhaust heat is insufficient to meet the heat demand. Electricity and heat are supplied to the demand side from the proposed systems, and no external sources are used. When the NN production-of-electricity prediction was introduced, the engine generator operating time was reduced by $12.5 \%$ in December and $16.7 \%$ for March and September. Moreover, an operation plan for the combined system exhaust heat is proposed, and the heat output characteristics of the back-up boiler are characterized.
\end{abstract}

Key words: Solar Cell, Diesel Engine Generator, Neural Network, Combined System, Prediction Algorithm

\section{Introduction}

Recently, the neural network (NN) has been proposed as a suitable statistical approach for classification and prediction problems ${ }^{(1),(2)}$. A NN can be easily used in prediction problems due to its simplicity and adaptive pattern recognition ability. The prediction of local weather using $\mathrm{NN}$ is low in cost compared to large-scale prediction of weather using a mainframe computer. The objectives of this study are to develop an algorithm based on a NN to predict the electricity production from a solar cell and to optimize the operation plan of a combined solar cell and diesel engine generator. A layered $\mathrm{NN}$ is developed to learn and teach based on weather data, which includes the amount of solar radiation and the outside air temperature. This system allows for the construction of a power supply system with low environmental impact that uses renewable energy. Several studies have focused on

${ }^{*}$ Received 17 Sep., 2009 (No. 09-0522) [DOI: 10.1299/jpes.4.27]

Copyright $(\odot 2010$ by JSME 
combining a solar cell and a diesel power plant ${ }^{(3)-(6)}$. However, in these papers, reductions in energy cost by predicting electricity production from the solar cell and power load prediction were not investigated with respect to the heat characteristics of the proposed systems. The estimated power and generation capacities of solar cells have been studied ${ }^{(7),(8)}$. The overall efficiency performance of solar cell systems about a variety of irradiation conditions was proposed by Mondol et al. ${ }^{(7)}$, and the accuracy of an artificial NN for estimating real-time maximum power generation from solar cells is studied by Syafaruddin et al. ${ }^{(8)}$. A NN prediction algorithm (PAS) was developed by Obara ${ }^{(9)}$. The relationship between prediction errors of the PAS and the energy cost was clarified, and the fuel consumption of an engine generator was proposed. However, although the output power from a solar cell was predicted using a NN in Ref. (9), the results were calculated and predicted on the order of weeks and days for the first weeks in February and August. Power was only supplied to the demand side, and heat from the proposed system was not considered. In the present paper, when the engine generator operates, exhaust heat from the engine is used to supply the demand. When the exhaust heat is less than the demand, a back-up boiler is used to supply the demand. Power and heat from the proposed system are used to supply the demand.

In addition, calculations and predicted results for solar cell electricity production as average values for each month and the energy supply characteristics of a solar cell and diesel engine generator are illustrated in this paper. Two systems are proposed in this work. The operation of the diesel engine generator is based on the fluctuation of the load in System 1, and a battery is not used. Therefore, because the engine is operated over a large area from a low to a high load, the average engine operation efficiency is low. On the other hand, in System 2 a battery is used to supply the demand when solar power is less than the demand, and the diesel engine generator operates at $25 \%$ or less of the battery residual quantity to work in safety Mode in the proposed system. Furthermore, operation of the engine generator is based on the charge or discharge of the battery, with maximum engine efficiency at maximum output power. Two operating methods are used in the two systems. In Method 1, we use actual electricity production calculations from the solar cell, while in Method 2, NN electricity production prediction results are used. This paper illustrates that engine generator operation time is shortened by introducing a NN prediction algorithm. The analysis error of the operation prediction is also considered. The heat output characteristics of the diesel engine and the back-up boiler are investigated.

\section{Procedure}

\subsection{System model}

A block diagram of the combined solar cell and diesel engine system is shown in Fig. 1. As shown in the figure, the proposed system consists of a solar cell, a diesel engine generator, a battery, a heat storage tank, a back-up boiler and a system controller. The power output from the solar cell can be supplied to the power demand through a DC-AC converter and inverter, which also charges the battery. The power output from the inverter is supplied to a power grid or sold off to utilities through an interconnection device. Table 1 shows the specifications of the solar cell, battery, engine and generator ${ }^{(10)}$. Two operating systems are used in this study. In System 1, a battery is not introduced into the system. When the solar cell power is less than the power demand, the diesel engine generator operates according to the load fluctuation, and the surplus power from the solar cell can be sold off. In System 2, the surplus power from the solar cell is used to charge a battery. The engine generator operates at a fixed load ( $3 \mathrm{~kW}$ output power) for maximum efficiency; the battery supplies the load when the power output from the solar cell is less than the demand. The battery capacity is measured for every sampling period. If the battery capacity drops to $25 \%$ or less 


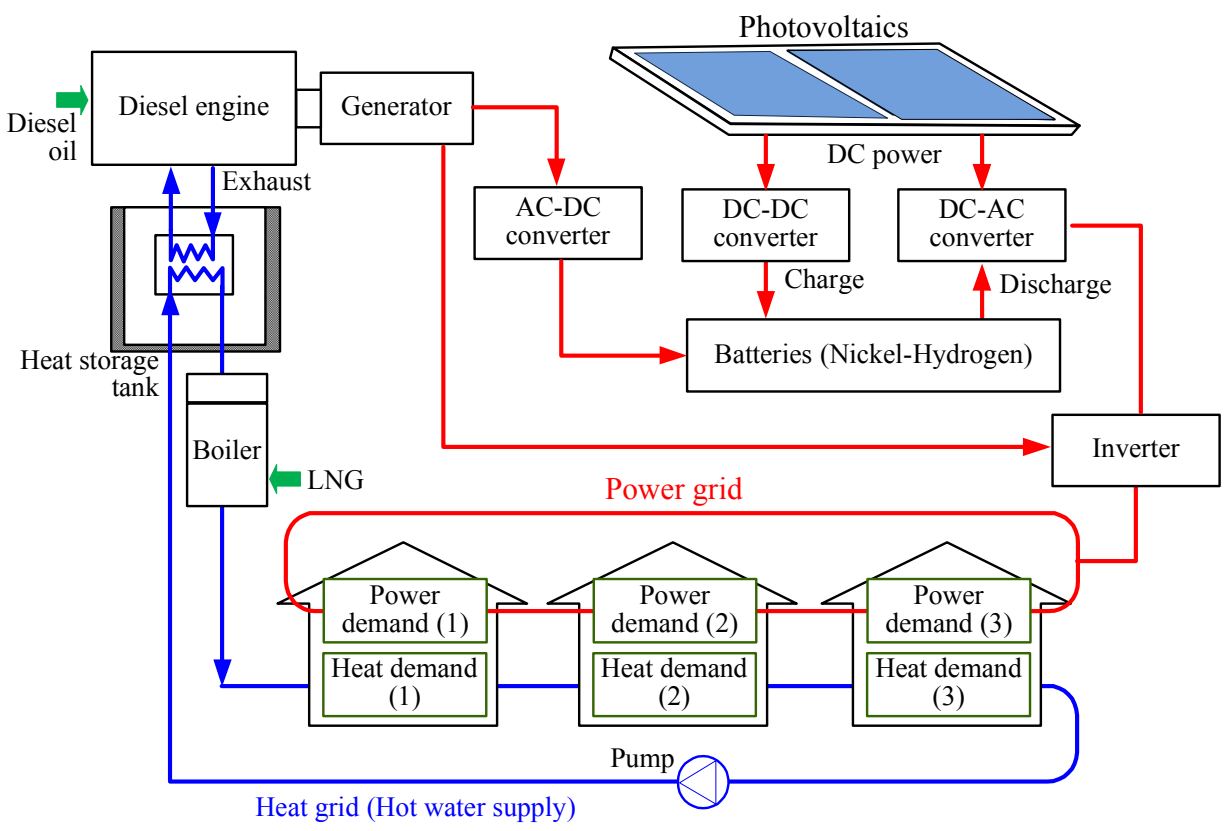

Fig. 1 System scheme

Table 1 System apparatus specifications

\begin{tabular}{|c|c|}
\hline Apparatus & Specifications \\
\hline Solar cell type & Multi crystalline silicon \\
Area and generation efficiency & $72 \mathrm{~m}^{2}, 14 \%$ \\
Temperature coefficient of a solar cell & $0.4 \% / \mathrm{K}$ \\
\hline Battery type & Nickel - Hydrogen \\
Battery efficiency, Battery capacity & $95 \%, 4 \mathrm{kWh}$ \\
\hline Engine type & Vertical straight \\
Number of cylinders & 4 cycle diesel, 2 cylinders \\
Total stroke volume, Rated shaft output & $451 \mathrm{cc}, 8.6 \mathrm{~kW}$ \\
Combustion type & Special swirl chamber \\
Compression ratio, Fuel & 24.5, Kerosene \\
Size, Dry weight & 369 X 385 X $485 \mathrm{~mm}, 60 \mathrm{kgf}$ \\
\hline Generator type & Single phase synchronized \\
Rated out, Rated voltage & $5 \mathrm{kVA}, 100 \mathrm{~V}$ \\
Frequency, Number of revolution & $50 \mathrm{~Hz}, 300 \mathrm{rpm}$ \\
Size & 200 X 221 X $359 \mathrm{~mm}$ \\
\hline
\end{tabular}

in the safety operation mode, the engine generator operates and charges the battery. The heat from the engine and boiler is used to supply the heat demand.

Figure 2 shows the output characteristics of a test diesel engine generator; the maximum power output generated from the diesel engine generator is $3 \mathrm{~kW}{ }^{(11)}$. The heat exhaust output from the engine generator includes engine-cooling water and exhaust gas. The heat exhaust is stored in a heat storage tank that supplies a back-up boiler. The engine generator efficiency is calculated using the approximate expression shown in Fig. 2(b).

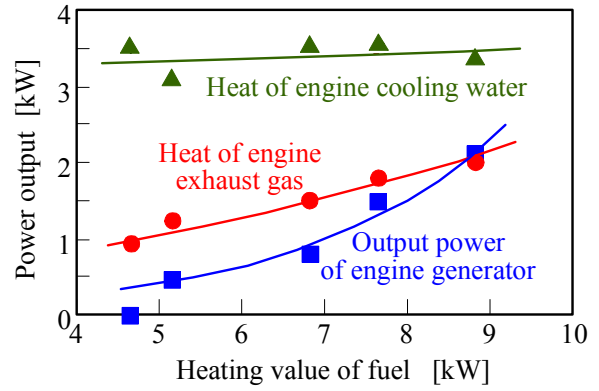

(a) Output characteristics of the engine generator

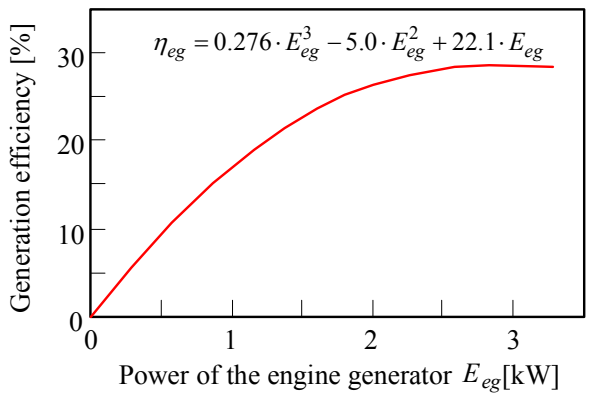

(b) Power generation efficiency of the diesel engine generator

Fig. 2 Output characteristics of the diesel engine generator at $1600 \mathrm{rpm}$ 


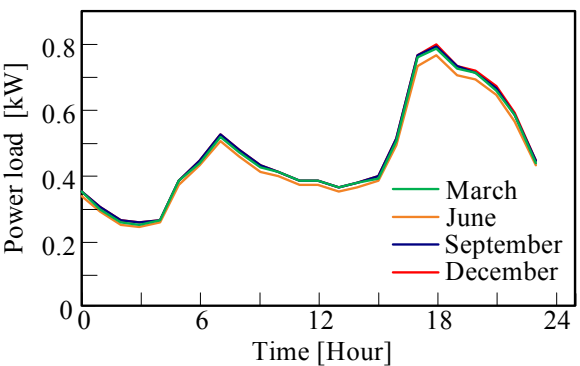

(a) Power demand

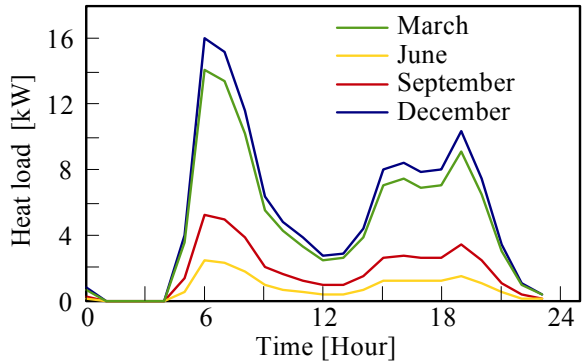

(b) Heat demand

Fig. 3 Power load and heat load of one household in Sapporo in Japan

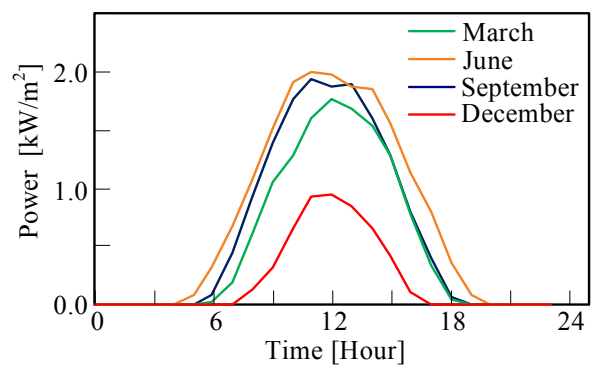

Fig. 4 Slope-face solar radiation

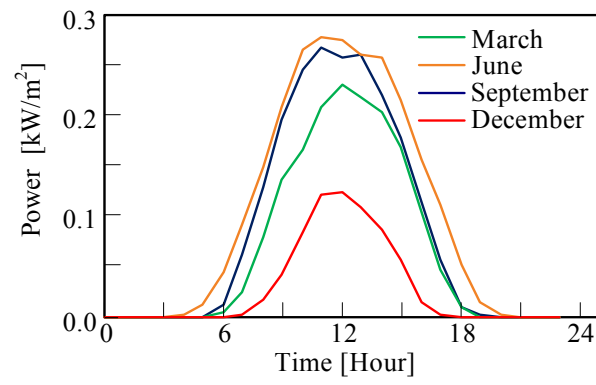

Fig. 5 Solar cell electricity production

\subsection{Examination methods}

Two methods were used to examine the two operating systems. In Method 1, the system operation plan depends on actual calculations of the power output from the solar cell. On the other hand, in Method 2, the production of electricity from the solar cell using a NN prediction algorithm is introduced, and the system operation plan is based on the NN predicted output results for the solar cell. In this paper, the operation plan of the engine generator is investigated using the results of Method 1 and Method 2.

\subsection{Energy demand patterns}

The power and heat demand patterns of a typical household in Sapporo city, Japan, are shown in Fig. $3^{(11),(12)}$. In this figure, the power demand pattern does not change significantly each month; this is because there is no cooling load in the summer in Sapporo. The electricity demand includes household appliances and electric lighting. Heat demand comes from heating, hot water supply and baths. The operating systems were introduced into three apartments with the load and heat patterns shown in Fig. 3, multiplied by three.

\section{Analysis Method}

\subsection{Amount of Slope-face Solar Radiation and Electricity Production of the Solar Cell}

Direct solar radiation intensity $\left(H_{D}\right)$ and sky solar radiation intensity $\left(H_{S}\right)$ are used to calculate the amount of slope-face solar radiation and the electricity production from the solar cell ${ }^{(9)-(14)}$. The formulas for direct solar radiation and the sky solar radiation are calculated using the following equations:

$$
H_{D}=I_{D} \cdot \cos \theta
$$

$\sin \theta=\cos \alpha \cdot \sin \delta-\sin \alpha \cdot \cos \varphi \cdot \cos \delta$

$H_{S}=0.5 \cdot I_{S} \cdot(1+\cos \beta)+0.5 \cdot \lambda \cdot I_{H} \cdot(1-\cos \beta)$ 
where $I_{D}$ is the direct solar radiation intensity, $I_{H}$ is the global solar radiation intensity, $I_{S}$ is the horizontal sky solar radiation, $\lambda$ is the reflection factor, $\theta$ is an incident angle to the acceptance surface of the sunlight, $\alpha$ is the latitude of the setting point, $\delta$ is the solar celestial declination, $\varphi$ is the hour angle and $\beta$ is the angle of the gradient of the acceptance surface. $H_{D}$ and $H_{S}$ are obtained from the standard weather, the solar radiation data base in the meteorology government office in Japan and AMEDAS (1990 to 2003) ${ }^{(14)}$.

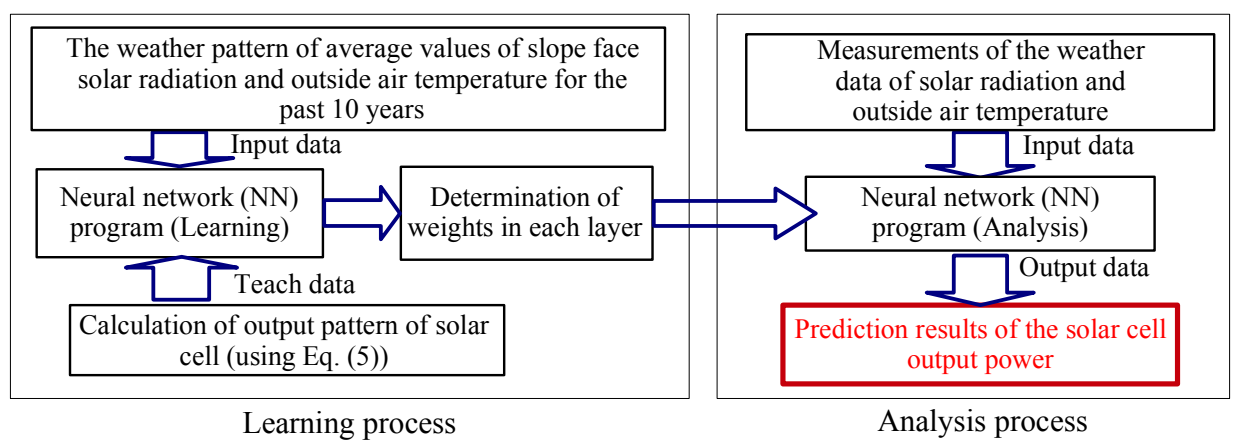

Fig. 6 Prediction algorithm of the solar cell electricity production

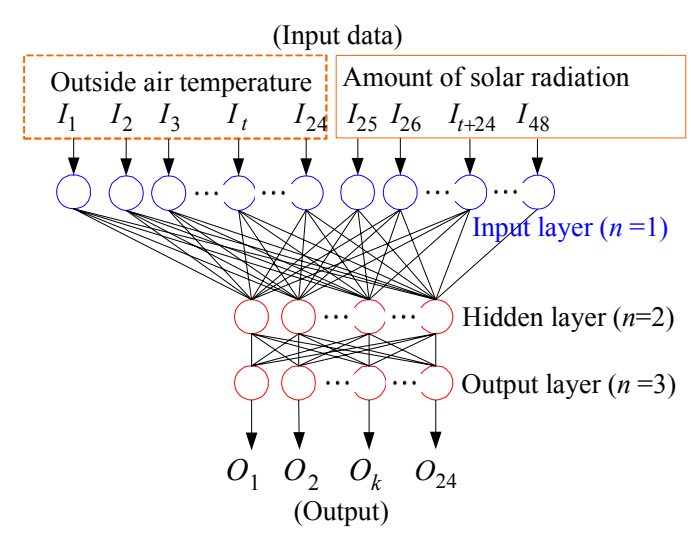

Fig. 7 The layered neural network of the prediction algorithm

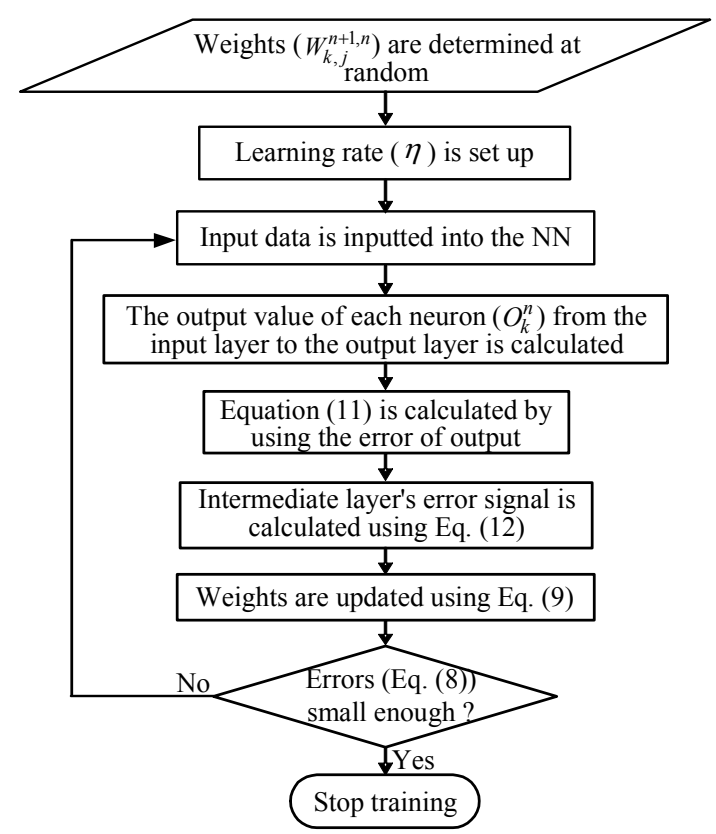

Fig. 8 The NN algorithm learning process calculation flow 
Equations 1 to 4 are used to calculate the slope-face solar radiation; the calculation results are shown in Fig 4. In this figure, the average values of slope-face solar radiation are calculated for December, March, June and April.

The following equation is used to calculate the average electricity production $P_{S}$ from the solar module ${ }^{(9)}$.

$$
P_{S}=S_{S} \cdot \eta_{S} \cdot\left(H_{D}+H_{S}\right) \cdot\left\{1-\left(T_{C}-T_{O}\right) \cdot\left(R_{T} / 100\right)\right\}
$$

where $P_{S}$ is the output power from the solar cell, $T_{c}$ is the temperature of the solar cell, $S_{S}$ is the area of the solar cell $\left(72 \mathrm{~m}^{2}\right), \eta s$ is the generation efficiency $(14 \%), R_{T}$ is the temperature coefficient $(0.4 \% / \mathrm{K})$ and $T_{o}$ is the reference temperature $(298 \mathrm{~K})$. Equation $(5)$ is used to calculate the solar cell electricity production, the calculation results are shown in Fig. 5. As shown in this figure, the average electricity production values from the solar cell are calculated for December, March, June and September.

\subsection{Proposed neural network algorithm}

The NN is suitable to predict the power output from the solar cell because of its speed, simplicity and high prediction performance ${ }^{(15)}$. The prediction algorithm of the electricity production of the solar cell uses a layered NN, as shown in the block diagram in Fig. 6. The structure of the layered $\mathrm{NN}$ is shown in Fig. 7; it consists of three layers: the input layer, the hidden layer and the output layer. The successful implementation of a NN depends on the training (learning) process. In the learning process, the connection weights between layers are determined following the total minimum error. First, all weights are chosen randomly, and the past weather pattern of a slope-face solar radiation and outside air temperature are used as input signals to the NN. The electricity production teaching data from the solar cell are input into the output layer. During the learning process, the learning rate is specified as 0.1 , and the sigmoid function is utilized for the input-output characteristics of the neurons. For each neuron, the teaching data is the calculation of output power from the solar cell using Eq. (5); the output of neuron $j$ in the $n$ layer is given as:

$O_{j}^{n}=\frac{1}{1+e^{-I_{j}^{n}}}$

The term $I_{j}^{n}$ in Eq. (6) is the input of neuron $j$ in layer $n$. It is calculated using the output $O_{k}^{n-1}$ and weight $w_{j, k}^{n, n-1}$ of neuron $k$ layer $n$-1, as follows:

$I_{j}^{n}=\sum_{k=1}^{L_{n-1}} w_{j, k}^{n, n-1} \cdot O_{k}^{n-1}$

where $j=1, \ldots ., L_{n}$, and $k=1, \ldots \ldots, L_{n-1}$

\subsection{Learning process}

First, all weights in the NN is determined randomly. When the random initial values are input into the proposed NN, the outputs agree with the correct answer with high precision. The past weather patterns, amount of slope face solar radiation and outside temperature are given to the NN, and the learning data is the actual output power from the solar cell. The 
mean squared errors (MSE) equation is described as:

$M S E_{N}=0.5 \cdot \sum_{j=1}^{L_{n}}\left(t_{j}-O_{j}^{N}\right)^{2}$

Where $t_{j}$ is the output target actual power, and $O_{j}^{N}$ is the estimated power value. The NN modifies the weights so that the MSE approaches $0.0055 \%$.

\subsection{Weight modification}

Equation 9 is used to calculate the corrected weighted $w_{i n}^{n, n-1}$ by using the weight before modification $w_{j, k}^{-n, n-1}$ and the amount of modification $\Delta w_{j, k}^{n, n-1}$. The amount of modification in Eq. (10) is expressed in Eq. (11). The partial differential of Eq. (10) is calculated using Eqs. (11) and (12) ${ }^{(16)}$

$\Delta w_{j, k}^{n, n-1}=w^{\text {new }}-w^{\text {old }}=w_{j, k}^{n, n-1}-w_{j, k}^{-n, n-1}$

$\Delta w_{j, k}^{n, n-1}=-\eta \frac{\partial M S E_{N}}{\partial w_{j, k}^{n, n-1}}=-\eta \frac{\partial M S E_{N}}{\partial I_{j}^{n}} \cdot O_{j}^{n-1}$

when $n=N$

$\frac{\partial M S E_{N}}{\partial I_{j}^{n}}=-\left(t_{j}-I_{j}^{N}\right) \cdot O_{j}^{N} \cdot\left(1-O_{j}^{N}\right)$

when $n<N$

$\frac{\partial M S E_{N}}{\partial I_{j}^{n}}=\left\{\sum_{L=1}^{L n} \frac{\partial M S E_{N}}{\partial I_{j}^{n+1}} \cdot w_{L, j}^{n+1, n}\right\} \cdot O_{j}^{n} \cdot\left(1-O_{j}^{n}\right)$

\subsection{Analysis flow of the learning process}

Figure 8 shows the proposed $\mathrm{NN}$ algorithm learning process analysis flow. All weights $w_{j, k}^{n, n-1}$ are determined randomly, and the learning rate $\eta$ in Eq. (10) is given to the program. The input data $I_{j}^{n}$ and teaching data $t_{j}$ are input into the program. The input and output data of each neuron are calculated. Equation (11) is calculated using $O_{j}^{n}$ and $t_{j}$, as well as Eq. (12). These results are used in Eq. (10), and $\Delta w_{j, k}^{n, n-1}$ is calculated. This value is given to Eq. (9) and the weight of each neuron is updated. The analysis error is calculated using

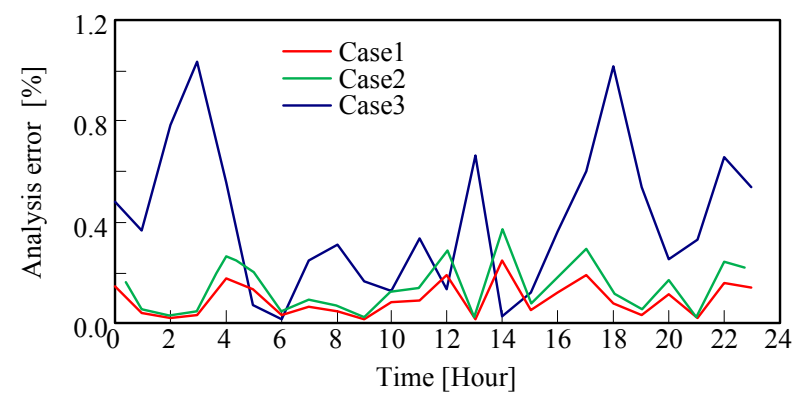

Fig. 9 Relation between input data and analysis error in March 
Eq. (8). When the analysis error is smaller than the previously defined value, the training process stops. On the other hand, if it is larger than the threshold value, the process is returns and calculates repeatedly.

\subsection{Relation between the input data and analysis error}

In this section, the relation between input data and analysis error is illustrated. Equation (8) is used to calculate the analysis error, as shown in Fig. 9. In this figure, the relation between the input data and analysis error is graphed for three cases: in case 1, the input includes all outside temperature data and solar radiation data that are the average daily values; in case $2, \pm 10 \%$ of random fluctuation is given to solar radiation; and in case 3 , $\pm 20 \%$ random fluctuation is given to solar radiation. As shown in Fig. 9, the variation of solar radiation influences the analysis. The biggest influence occurs in case 3 .

\section{Results and Discussion}

The predicted values for the electricity production from the solar sell using NN prediction algorithm are shown in Fig. 10. Figure 11 presents the average power generation prediction error values from the solar cell; this figure was obtained by subtracting Fig. 10 from Fig. 5. In Fig. 11, the average error percentages are 25\%, 29\%, 19\% and 26\% for December, March, June and September, respectively. These values are different because of the differences in slope-face solar radiation and outside air temperature for each month. Figure 12(a) is obtained by subtracting the power demand of three houses from the solar cell electricity production (multiplying Fig. 5 by $72 \mathrm{~m}^{2}$ to transfer values from $\mathrm{kW} / \mathrm{m}^{2}$ to $\mathrm{kW}$ ).

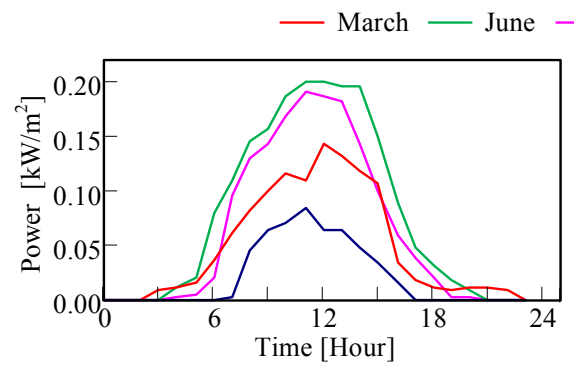

Fig. 10 Predictive values of the solar cell electricity

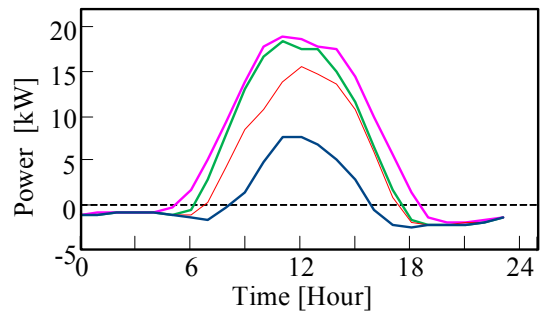

(a) Using actual output power

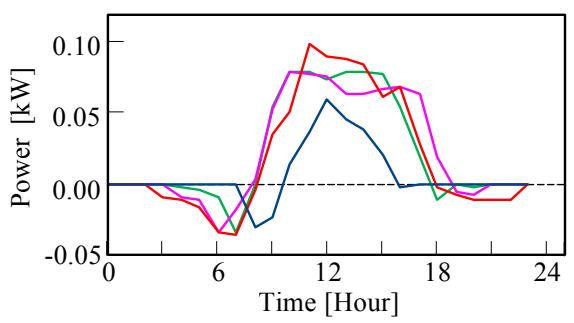

Fig. 11 Error in power generation prediction

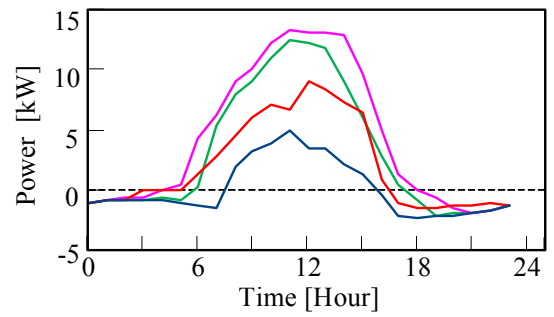

(b) Using NN prediction power

Fig. 12 Power results generated by subtracting the power demand from the solar cell output power

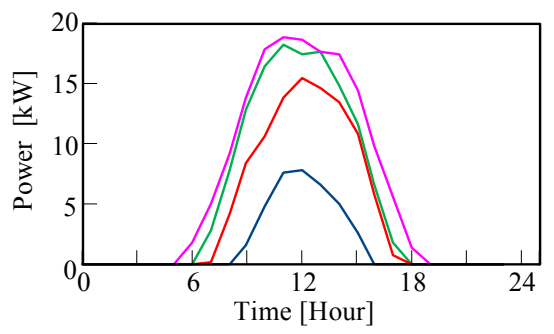

(a) Method 1

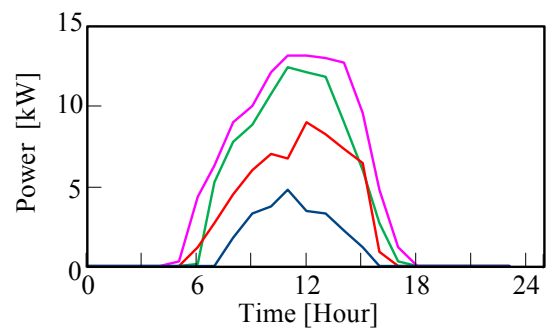

(b) Method 2

Fig. 13 Electricity sales to utilities in System 1 
Furthermore, Fig. 12(b) is obtained by subtracting the power demand from the NN predictive values of electricity output from the solar cell.

\subsection{System 1 Results}

The surplus power of the solar cell is sold as shown in Fig. 13. When the electricity output from the solar cell is insufficient compared with the power demand, the engine generator operates and supplies the demand, as shown in Figs. 14 and 15. The peak values of engine heat exhaust are shown in Table 2. As shown in this table, the peak values of heat exhaust are reduced by $3.3 \%, 7.5 \%, 1.1 \%$ and $2.7 \%$ by introducing the $\mathrm{NN}$ algorithm for each month. In addition, the peak value of engine generator efficiency is 28.1 for the two methods. The engine generator operates with low efficiency because it operates according to load fluctuation. When the engine heat exhaust is less than the demand, the back-up boiler supplies the demand side, as shown in Fig. 16. In this figure, the peak heat values from the back-up boiler in case of Method 1 are 156 and $26 \mathrm{MJ}$ at 6:00 a.m. for September and June, respectively, and also 145 and $54 \mathrm{MJ}$ at 7:00 a.m. for March and September, respectively. Moreover, in Method 2, the peak heat values from the back-up boiler are 155, 153, 26 and $57 \mathrm{MJ}$ for each month at 6:00 in the morning. In System 1, the electricity is sold to the utilities, so the overall system efficiency is good.

Table 2. Peak values of exhaust heat from the engine generator in MJ

\begin{tabular}{|c|c|c|c|}
\hline Month & Method 1 & Method 2 & Time \\
\hline December & 20.97 & 20.27 & $06: 00: 00$ PM \\
\hline March & 20.3 & 18.77 & $07: 00: 00$ PM \\
\hline June & 19.6 & 19.39 & $09: 00: 00$ PM \\
\hline September & 20.21 & 19.67 & $07: 00: 00$ PM \\
\hline
\end{tabular}

\subsection{System 2 results}

A battery is used to supply the demand side when the output power from the solar cell is lower than the demand, as shown in Fig. 17. The surplus power from the solar cell is used to charge the battery. The diesel engine generator operates according to the charge or discharge of the battery, as shown in Fig. 18. The engine generator operates an average of 8, 6, 4, and 6 hours in Method 1 and 7, 5, 4, and 5 hours in Method 2 for each month, respectively. During these engine generator operating hours, the heat is supplied to the demand side. When comparing Fig. 18 (a) with Fig. 18 (b), the operating period of the engine generator is shortened by introducing the NN prediction algorithm. The engine operating time is reduced by $12.5 \%$ in December and $16.7 \%$ for March and September. The operation plan of the back-up boiler is shown in Fig. 19. In this figure, the peak values of heat from the back-up boiler are 8.6, 8.5, 8.3, 8.6 $\mathrm{MJ}$ for each month at 18:00 in Method 1. In addition, for Method 2, the peak values are 8.6, 8.3 and 8.6 MJ for December, June and September at 18:00, respectively, and 8.2 $\mathrm{MJ}$ for March at 17:00. The average total engine heat is 51, 39, 26 and $38 \mathrm{MJ}$; furthermore, the back-up boiler provides 77, 89, 97 and $90 \mathrm{MJ}$ in Method 1 for each month. Moreover, for Method 2, the average values of total engine heat is 39, 32, 26 and 32 $\mathrm{MJ}$, respectively, and the average heat from the back-up boiler is $87,87,96$ and $95 \mathrm{MJ}$ for each month. 


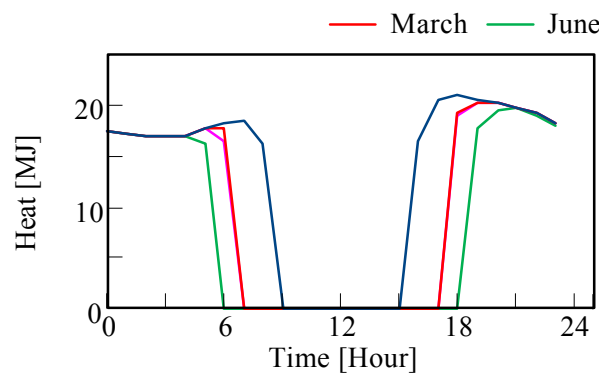

(a) Method 1

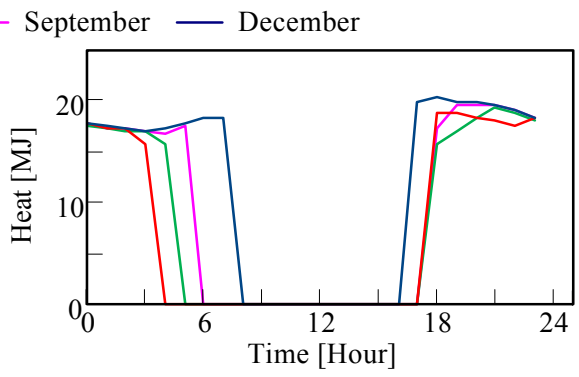

(b) Method 2

Fig. 14 Engine generator heat exhaust

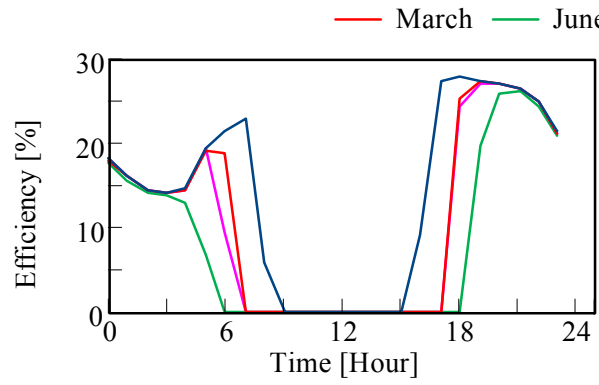

(a) Method 1

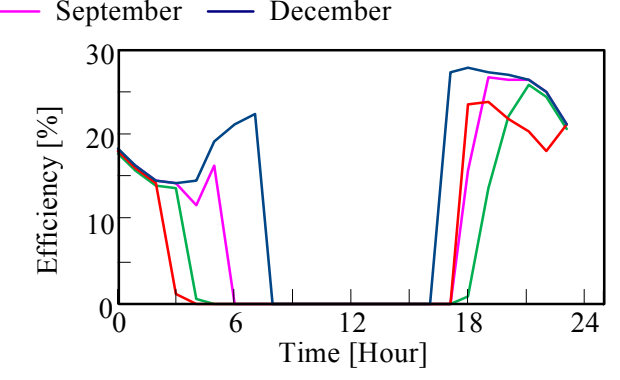

(b) Method 2

Fig. 15 Engine generator efficiency

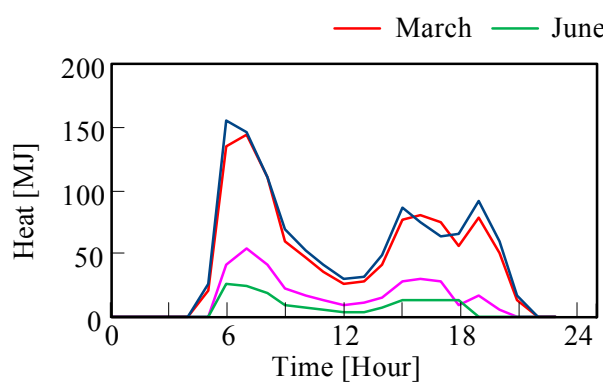

(a) Method 1

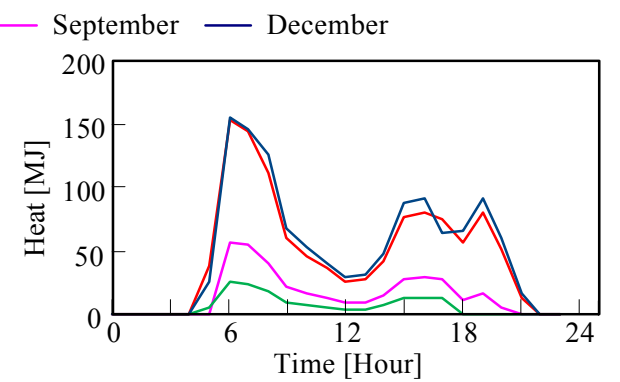

(b) Method 2

Fig. 16 Heat from the back-up boiler in System 1

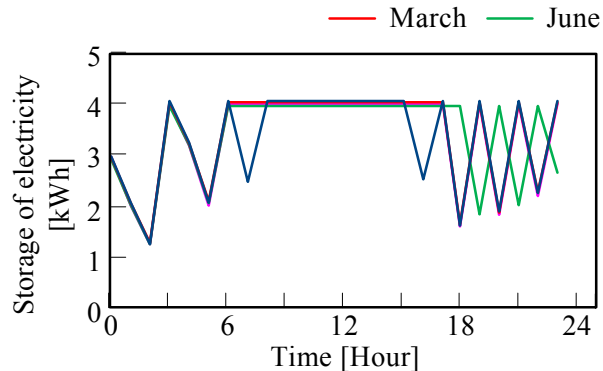

(a) Method 1

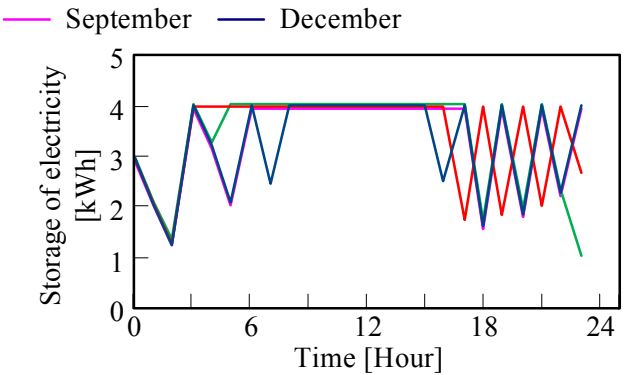

(b) Method 2

Fig. 17 Battery operation plan

\section{Conclusions}

A prediction algorithm using $\mathrm{NN}$ for electricity production from a solar cell is developed. The proposed system consists of two systems: System 1 and System 2. A battery is not introduced into System 1. An engine generator is operated in System 1 such that the solar cell power efficiency may be covered. In this case, because the operating range of the engine generator is wide, partial load operation with low efficiency occurs frequently. In addition, because the electricity is sold to utilities, the performance of System 1 is good. The engine generator operates at a fixed load (3-kW output power) of maximum efficiency in System 2; furthermore, the battery supplies the load with electricity when the power from the solar cell is insufficient compared to demand. The energy supply characteristics of the 


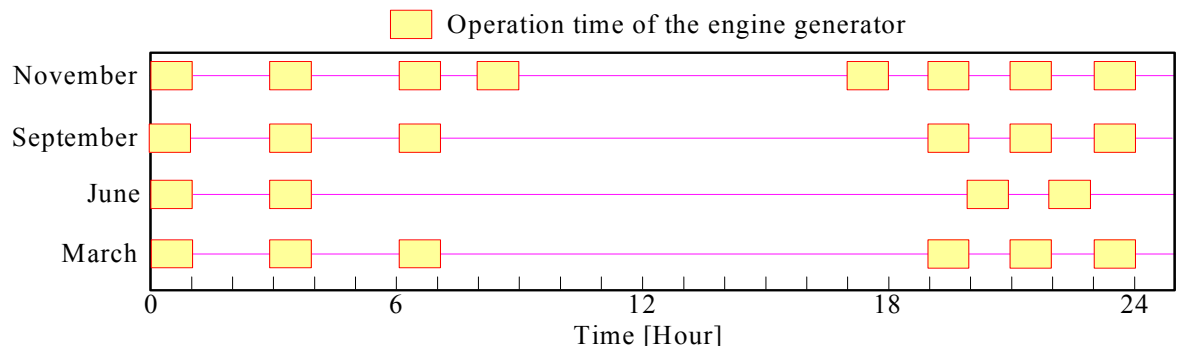

(a) Method 1

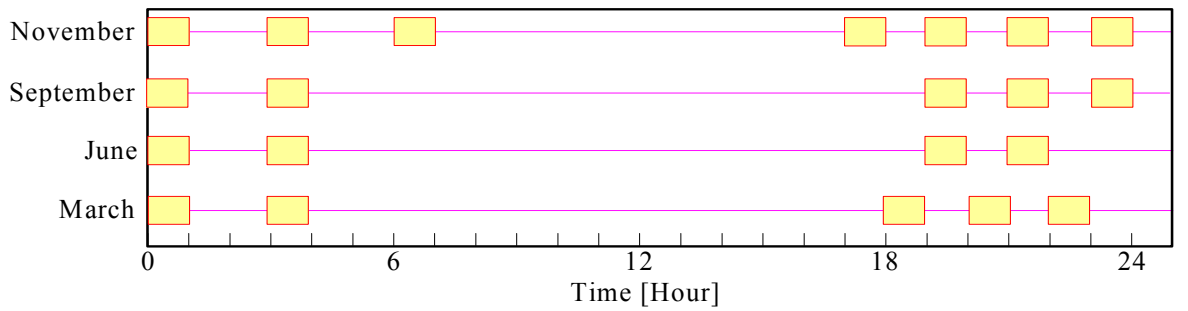

(b) Method 2

Fig. 18 Analysis results of the engine generator operation plan

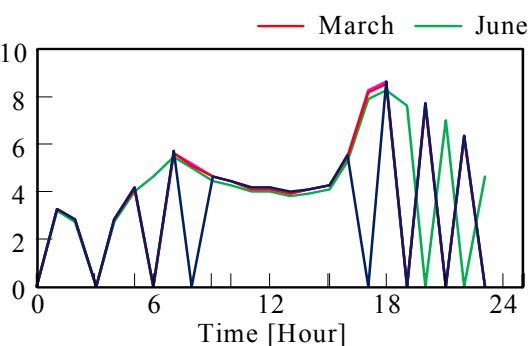

(a) Method 1

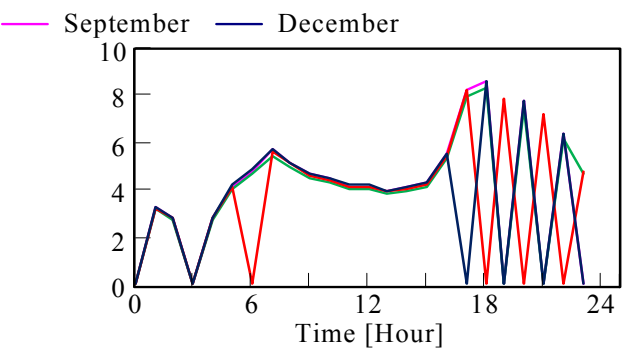

(b) Method 2

Fig. 19 Heat from the back-up boiler in System 2

combined solar cell and diesel engine generator system are proposed in the two methods for the two systems. In Method 1, the operation plan of the system depends on the calculated solar cell electricity production results. On the other hand, the system operation plan in Method 2 introduces the output power results from the NN prediction algorithm. The average values for the prediction error of electricity production from the solar cell are $25 \%$, $29 \%, 19 \%$ and $26 \%$ for December, March, June and September, respectively. The operating period of the engine generator is shortened by introducing the NN prediction algorithm for the power and heat supplied to the demand side. The engine operating time is reduced by $12.5 \%$ in December and $16.7 \%$ for March and September. The diesel engine heat characteristics are described, and a back-up boiler operation plan is developed.

\section{Acknowledgments}

This work was partially supported by a Grant-in-Aid for Scientific Research (C) from JSPS.KAKENHI (20560204).

\section{References}

(1) Anstett, M., Kreider, J.F.: "Application of Neural Networking Models to Predict Energy use", ASHRAE Transaction, Vol. 99, No. 1, (1993), pp. 505-517.

(2) Kreider, J.F., Wang, X.A.: "Improved Artificial Neural Networks for Commercial Building Energy Use Prediction", Solar Engineering, Vol. 1, (1992), pp. 361-366.

(3) M. Muselli, G. Notton and A. Louche: "Design of Hybrid-Photovoltaic Power Generator with Optimization of Energy Management", Solar Energy, Vol. 65, No. 3, (1999), pp. 143-157.

(4) M. Ashari and C.V. Nayar: "An optimum Dispatch Strategy using Set Points for a 
Photovolatic (PV)-Diesel-Battery Hybrid Power System”, Solar Energy, Vol. 66, No. 1, (1999), pp. 1-9.

(5) Shigehiro Yamamoto, Kazuyoshi Sumi, Eiichi Nishikawa, Takeshi Hashimoto: "An Operating Method using Prediction of Photovoltaic Power for a Photovoltaic-Diesel Hybrid Power Generation System", Transaction of Institute of Electrical Engineers of Japan, B, Power and Energy, Vol. 124, No. 4, (2004), pp. 521-530

(6) Ismail Y, Kemmoku Y, Takikawa H and Sakakibara T: "An Operating Method for Fuel Saving in a Stand-Alone Wing/Diesel/Battery System”, Journal of Japan Solar Energy Society, Vol. 28, No. 2, (2002), pp. 31-38.

(7) J.D. Mondol, Y.G Yohanis, and B. Norton: "Comparison of Measured and Predicted Long Term Performance of a Gird Connected Photovoltaic System”, Energy Conversion \& Mangement, Vol. 48, No. 4, (2007), pp.1065-1080.

(8) Syafaruddin, Engin Karatepe and Takashi Hiyama: "ANN based Real-Time Estimation of Power Generation of Different PV Module Types", Transaction of Institute of Electrical Engineers of Japan, B, Power and Energy, Vol. 129, No. 6, (2009), pp. 783-790.

(9) Shin'ya Obara: "Fuel Reduction Effect of the Solar Cell and Diesel Engine Hybrid System with a Prediction Algorithm of Solar Power Generation", Journal of Power and Energy Systems, Vol. 2, (2008), No. 4, pp. 1166-1177

(10) SANYO Nickel-Metal Hydride Production Information, http://www.sanyo.co.jp

(11) Shin'ya Obara: "Improvement of Power Generation Efficiency of an Independent Micro Grid Composed of Distributed Engine Generators", ASME Transl. Journal of Energy Resources Technology, Vol. 129, Issue 3, (September 2007), pp. 190-199.

(12) Shin'ya Obara:" Cost of an Independent Micro-grid with Control of Power Output Sharing of a Distributed Engine Generator", Journal of Thermal Science and Technology, Vol. 2, No. 1, (2007), pp. 42-53.

(13) Solar Energy Utilization Handbook, Japan Solar Energy Society, Ohmsha, Ltd, (1985), pp. $10-88$.

(14) NEDO Technical information database, Standard meteorology and Solar radiation data (METPV-3), http://www.nedo.co.jp.

(15) R.M. Kil and Y. Song: "Random Search Based on Genetic Operators, "Lecture Notes in Artificial Intelligence", Spring-Verlag, Vol. 1285, (1997), pp. 196-205.

(16) Haykin, S., Neural Networks: A Comprehensive Foundation (Prentice Hall International Edition), Prentice-Hall, Upper Saddle River, NJ, 1998. 